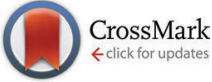

Cite this: Phys. Chem. Chem. Phys., 2016, 18, 15191

Received 26th February 2016, Accepted 10th May 2016

DOI: $10.1039 / c 6 c p 01352 j$

www.rsc.org/pccp

\title{
Halogenated earth abundant metalloporphyrins as photostable sensitizers for visible-light-driven water oxidation in a neutral phosphate buffer solution $\uparrow$
}

\author{
Hung-Cheng Chen, Joost N. H. Reek, René M. Williams and Albert M. Brouwer*
}

\begin{abstract}
Very photostable tetrachloro-metalloporphyrins were developed as sensitizers for visible-light-driven water oxidation coupled to cobalt based water-oxidation catalysts in concentrated $(0.1 \mathrm{M})$ phosphate buffer solution. Potassium persulfate $\left(\mathrm{K}_{2} \mathrm{~S}_{2} \mathrm{O}_{8}\right)$ acts as a sacrificial electron acceptor to oxidize the metalloporphyrin photosensitizers in their excited states. The radical cations thus produced drive the cobalt based water-oxidation catalysts: $\mathrm{CO}_{4} \mathrm{O}_{4}$-cubane and $\mathrm{Co}\left(\mathrm{NO}_{3}\right)_{2}$ as pre-catalyst for cobalt-oxide $\left(\mathrm{CoO}_{x}\right)$ nanoparticles. Two different metalloporphyrins $\left(\mathrm{Cu}\left({ }^{\prime}\right)\right.$ and $\left.\mathrm{Ni}\left({ }_{\mathrm{I}}\right)\right)$ both showed very high photostability in the photocatalytic reaction, as compared to non-halogenated analogues. This indicates that photostability primarily depends on the substitution of the porphyrin macrocycle, not on the central metal. Furthermore, our molecular design strategy not only positively increases the electrochemical potential by $120-140 \mathrm{mV}$ but also extends the absorption spectrum up to $\sim 600 \mathrm{~nm}$. As a result, the solar photon capturing abilities of halogenated metalloporphyrins $(\mathrm{Cu}(\mathrm{II})$ and $\mathrm{Ni}(\mathrm{II}))$ are comparable to that of the natural photosynthetic pigment, chlorophyll $a$. We successfully demonstrate long-term ( $>3$ h) visible-light-driven water oxidation using our molecular system based on earth-abundant (first-row transition) metals in concentrated phosphate buffer solution.
\end{abstract}

\section{Introduction}

One of the options to create energy in a sustainable way is the solar-to-fuel approach. ${ }^{1}$ Solar-driven splitting of water to produce $\mathrm{O}_{2}$ and $\mathrm{H}_{2}$ via artificial photosynthesis is the key challenge in this field. ${ }^{2}$ The water splitting reaction consists of two half reactions that are frequently studied as independent reactions: a water oxidation reaction in which water is oxidized to give oxygen and protons and a proton reduction reaction that gives molecular hydrogen. In homogeneous solution studies on lightdriven water oxidation, three components are required to achieve photocatalytic activity: a sacrificial electron acceptor, a photosensitizer (PS) and a water oxidation catalyst (WOC). ${ }^{3}$ A significant number of water oxidation catalysts has been reported in the last decade including $\mathrm{Ru}^{4}{ }^{4} \mathrm{Ir}^{5} \mathrm{Mn}^{6}{ }^{6} \mathrm{Co},{ }^{7} \mathrm{Fe},{ }^{8}$ and $\mathrm{Cu}^{9}$ complexes ${ }^{10}$ as well as related micro- or nano-scale materials such as iridium oxide, and cobalt oxide. ${ }^{11,12}$ Less effort has been invested in the development of photosensitizers for

van't Hoff Institute for Molecular Sciences, Universiteit van Amsterdam,

Science Park 904, 1098 XH Amsterdam, The Netherlands.

E-mail: A.M.Brouwer@uva.nl

$\dagger$ Electronic supplementary information (ESI) available: The experimental procedures for the synthesis of all the porphyrins, the electrochemical characterization, spectroscopy and photocatalytic setup are described. See DOI: 10.1039/ c6сp01352j homogenous photocatalytic water oxidation and photoanode devices. Currently, mainly Ru polypyridine complexes are used as sensitizers. ${ }^{13-16}$ On the other hand, metalloporphyrins could be powerful alternatives. ${ }^{17}$ The excited photosensitizer reacts with the sacrificial electron acceptor to produce the photosensitizer radical cation $\mathrm{PS}^{\bullet+}$ (Scheme 1). ${ }^{18}$ This then oxidizes the WOC, provided that the redox potential $E\left(\mathrm{PS}^{\bullet+} / \mathrm{PS}\right)$ is high enough $(>1.20 \mathrm{~V}$ vs. NHE, considering that the WOC typically function with moderate overpotentials $\eta \leq 400 \mathrm{mV}$, under neutral conditions). ${ }^{19}$ Although the potentials in metalloporphyrins can be varied by changing the central metal atom, ${ }^{20}$ only few of these porphyrins have a sufficiently high reduction potential of their radical cations. Recently, systems with a highly positive potential $>1.40 \mathrm{~V}$ vs. NHE were reported, e.g. a Zn(II)-porphyrin

$$
\begin{aligned}
& \mathrm{PS}+\mathrm{hv} \longrightarrow \mathrm{PS}^{*} \\
& \mathrm{PS}^{*}+\mathrm{S}_{2} \mathrm{O}_{8}{ }^{2-} \longrightarrow \mathrm{PS}^{*+}+\mathrm{SO}_{4}{ }^{-}+\mathrm{SO}_{4}{ }^{2-} \\
& \mathrm{PS}+\mathrm{SO}_{4}{ }^{--} \longrightarrow \mathrm{PS}^{*+}+\mathrm{SO}_{4}{ }^{2-} \\
& 4 \mathrm{PS}^{++}+2 \mathrm{H}_{2} \mathrm{O} \stackrel{\mathrm{WOC}}{\longrightarrow} \mathrm{O}_{2}+4 \mathrm{H}^{+}+4 \mathrm{PS} \\
& 2 \mathrm{~S}_{2} \mathrm{O}_{8}{ }^{2-}+2 \mathrm{H}_{2} \mathrm{O}+2 h v \stackrel{\mathrm{WOC}}{\longrightarrow} \mathrm{O}_{2}+4 \mathrm{H}^{+}+4 \mathrm{SO}_{4}{ }^{2-}
\end{aligned}
$$

Scheme 1 Light-driven water oxidation mechanism for the three-component system used here. 
with strongly electron withdrawing pentafluorophenyl substituents and a Pt(II)-porphyrin, ${ }^{21,22}$ and these were successfully used for light-driven water oxidation under neutral conditions. More recently, Mallouk et al. reported a series of free-base porphyrins with a broad range of potentials from 1.23 to $1.50 \mathrm{~V} v s$. NHE, and also successfully demonstrated light driven water splitting using photoelectrodes obtained by co-deposition of these porphyrins and $\mathrm{IrO}_{2} \cdot{ }^{23,24}$

Because proton-coupled electron transfer (PCET) plays a key kinetic role in catalytic water-oxidation mechanisms, ${ }^{25}$ buffer base and concentration dramatically influence the catalytic activity. ${ }^{26}$ Moreover, in model studies that focus on catalytic water oxidation progressive acidification of the reaction medium occurs at higher conversion, resulting in less favorable thermodynamics. ${ }^{27} \mathrm{~A}$ high buffer capacity is required to assure good proton management. To address these issues, aqueous phosphate salts, such as potassium phosphate $\left(\mathrm{KPi}, \mathrm{p} K_{\mathrm{a}}=7.21\right)$ are ideal buffer systems for studying light-driven water oxidation under neutral conditions. The hydrogen phosphate ion has been proven to act as an efficient proton acceptor in the oxygenproducing reaction under nearly neutral conditions. ${ }^{28}$ Therefore, concentrated and (nearly) neutral phosphate buffer is the preferred medium for the study of water oxidation.

In order to produce solar fuel on an industrial scale, it is necessary to make large scale and long-term stable artificial photosynthetic devices. Consequently, cost-effective and robust materials are required to build devices based on molecular components. ${ }^{2}$ Importantly, the usage of earth abundant metals in molecular systems for visible-light-driven water oxidation in near-neutral buffer solution is still a big challenge. The $\beta$-halogenated metalloporphyrins and metallocorroles as robust catalysts for water oxidation, proton reduction and other chemical reactions have been reported in the literature. ${ }^{29-33}$ Moreover, it is known that halogenation at the pyrrole $\beta$-positions of porphyrins can positively shift the electrochemical potential for its oxidation. ${ }^{34}$ Inspired by this molecular design strategy we report here new photostable metalloporphyrin sensitizers with suitable potentials $E\left(\mathrm{PS}^{\bullet+} / \mathrm{PS}\right)$ using only earth abundant metals for light-driven water oxidation. We combine the photosensitizers with two Co-based water oxidation catalysts (WOC), thus completely avoiding the use of precious metals. The chemical structures are shown in Fig. 1. Our light-driven water oxidation studies were performed in concentrated $(0.1 \mathrm{M})$ phosphate buffer solution containing a sacrificial electron acceptor $\left(\mathrm{K}_{2} \mathrm{~S}_{2} \mathrm{O}_{8}\right)$.

\section{Results and discussion}

\section{Photophysical and electrochemical studies}

The chlorinated $\mathrm{Cu}(\mathrm{II})$ and $\mathrm{Ni}(\mathrm{II})$ derivatives of 5,10,15,20-tetrakis(4-methoxycarbonylphenyl)-porphyrin, bearing four halogens at the $\beta$-pyrrole positions, were prepared in high yield (up to 70\%) using a modified literature procedure. ${ }^{34}$ The UV-Vis absorption spectra and cyclic voltammograms of the compounds were obtained in $\mathrm{CH}_{2} \mathrm{Cl}_{2}$ at $298 \mathrm{~K}$. Data on the molar absorption

\section{Photosensitizer}

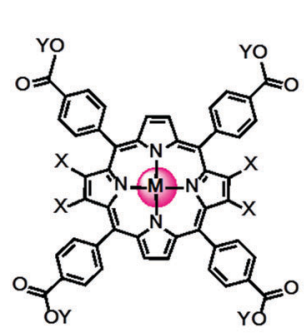

$\mathrm{Cu}(\mathrm{II})-\mathrm{TCMePP}: \mathrm{M}=\mathrm{Cu}, \mathrm{X}=\mathrm{H}, \mathrm{Y}=\mathrm{Me}$ $\mathrm{Cu}(\mathrm{II})-\mathrm{TClTCMePP}: \mathrm{M}=\mathrm{Cu}, \mathrm{X}=\mathrm{Cl}, \mathrm{Y}=\mathrm{Me}$

$\mathrm{Ni}(\mathrm{II})-\mathrm{TCM} P \mathrm{P}: \mathrm{M}=\mathrm{Ni}, \mathrm{X}=\mathrm{H}, \mathrm{Y}=\mathrm{Me}$ $\mathrm{Ni}(I I)-\mathrm{TClTCMePP}: \mathrm{M}=\mathrm{Ni}, X=\mathrm{Cl}, Y=\mathrm{Me}$

water-soluble :

$\mathrm{Cu}(\mathrm{II})$-TCPP : $\mathrm{M}=\mathrm{Cu}, \mathrm{X}=\mathrm{H}, \mathrm{Y}=\mathrm{H}$

$\mathrm{Cu}(\mathrm{II})$-TCITCPP : $\mathrm{M}=\mathrm{Cu}, \mathrm{X}=\mathrm{Cl}, \mathrm{Y=H}$

$\mathrm{Ni}(\mathrm{II})$-TCPP : $M=\mathrm{Ni}, X=\mathrm{H}, Y=\mathrm{H}$

$\mathrm{Ni}(\mathrm{II})-\mathrm{TCITCPP}: \mathrm{M}=\mathrm{Ni}, \mathrm{X}=\mathrm{Cl}, \mathrm{Y}=\mathrm{H}$

\section{Water-oxidation catalyst}

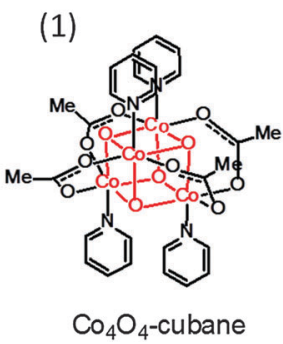

(2)

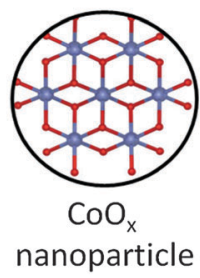

Fig. 1 Chemical structures of $\mathrm{Cu}(I)$ - and $\mathrm{Ni}\left({ }^{\prime \prime}\right)$-porphyrinphotosensitizers and water oxidation catalyst: (1) $\mathrm{CO}_{4} \mathrm{O}_{4}$-cubane, (2) representation of $\mathrm{CoO}_{x}$ nanoparticle formed from $\mathrm{Co}\left(\mathrm{NO}_{3}\right)_{2}$ pre-catalyst. ${ }^{7,35,36}$

Table 1 UV-visible spectral data $\left(\lambda_{\max }, \mathrm{nm}, \varepsilon \times 10^{-4} \mathrm{M}^{-1} \mathrm{~cm}^{-1}\right)$, the first triplet state energy (vs. eV) and the potential ( $V$ vs. NHE) for the first oxidation of metalloporphyrins

\begin{tabular}{|c|c|c|c|c|c|}
\hline \multirow[b]{2}{*}{ Molecule } & \multicolumn{5}{|c|}{$\lambda_{\max }, \mathrm{nm}(\varepsilon)$} \\
\hline & Soret & $Q_{x}$ & $Q_{y}$ & $E\left(T_{1}\right)^{c}$ & $E\left(\mathrm{PS}^{\bullet+} / \mathrm{PS}\right)$ \\
\hline$\overline{\mathrm{Cu}(\mathrm{II})-\mathrm{TCMePP}}{ }^{a}$ & $417(38.2)$ & $539(2.2)$ & $574(\mathrm{sh})$ & 1.53 & 1.32 \\
\hline $\mathrm{Cu}(\mathrm{II})$-TClTCMePP ${ }^{a}$ & $423(34.6)$ & $548(2.0)$ & 591 (sh) & 1.73 & 1.44 \\
\hline $\mathrm{Cu}(\mathrm{II})-\mathrm{TCPP}^{b}$ & $407(23.2)$ & $550(1.6)$ & 592 (sh) & 1.47 & $1.13^{d}$ \\
\hline $\mathrm{Cu}(\mathrm{II})-\mathrm{TClTCPP}^{b}$ & $404(22.2)$ & $554(1.5)$ & $592(\mathrm{sh})$ & 1.46 & $1.22^{d}$ \\
\hline $\mathrm{Ni}\left(\right.$ II)-TCMePP ${ }^{a}$ & $415(33.2)$ & $528(2.4)$ & $562(\mathrm{sh})$ & - & 1.37 \\
\hline $\mathrm{Ni(II)-TClTCMePP}{ }^{a}$ & $425(29.4)$ & $542(2.0)$ & $583(\mathrm{sh})$ & - & 1.51 \\
\hline $\mathrm{Ni}\left(\right.$ II)-TCPP ${ }^{b}$ & $406(22.2)$ & $529(1.6)$ & $565(\mathrm{sh})$ & - & $1.04^{d}$ \\
\hline $\mathrm{Ni}\left(\right.$ III)-TClTCPP ${ }^{b}$ & 404 (19.5) & 539 (1.6) & $580(\mathrm{sh})$ & - & $1.33^{d}$ \\
\hline
\end{tabular}

${ }^{a}$ In $\mathrm{CH}_{2} \mathrm{Cl}_{2} .{ }^{b}$ In phosphate buffer. ${ }^{c}$ Derived from the maxima of the emission bands in Fig. S1 (ESI). ${ }^{d}$ Derived from the first peaks in the differential pulse voltammograms (DPV, Fig. S8 (ESI)).

coefficients and the potentials $E\left(\mathrm{PS}^{\bullet+} / \mathrm{PS}\right)$ for various metalloporphyrins used in this study are collected in Table 1 . The absorption spectra of all metalloporphyrins studied are dominated by bands that can be attributed to spin-allowed $\pi-\pi$ transitions with an intense Soret band around $400 \mathrm{~nm}$ and moderately intense $\mathrm{Q}$ bands in the range 500-600 nm, which are shown in Fig. 2.

For halogenated meso-tetraarylporphyrins, the electronwithdrawing halogen atoms at the $\beta$-positions reduce the energies of both the HOMOs and LUMOs, and cause a disruption of the planarity of the porphyrin macrocycle framework, reducing the HOMO-LUMO gap..$^{34,37,38}$ The net result is a small lowering of the HOMO energies and a greater stabilization of the LUMOs in halogenated metallo-porphyrins. ${ }^{38}$ Consequently, spectral red-shifts of the Soret and Q-bands of porphyrins are 

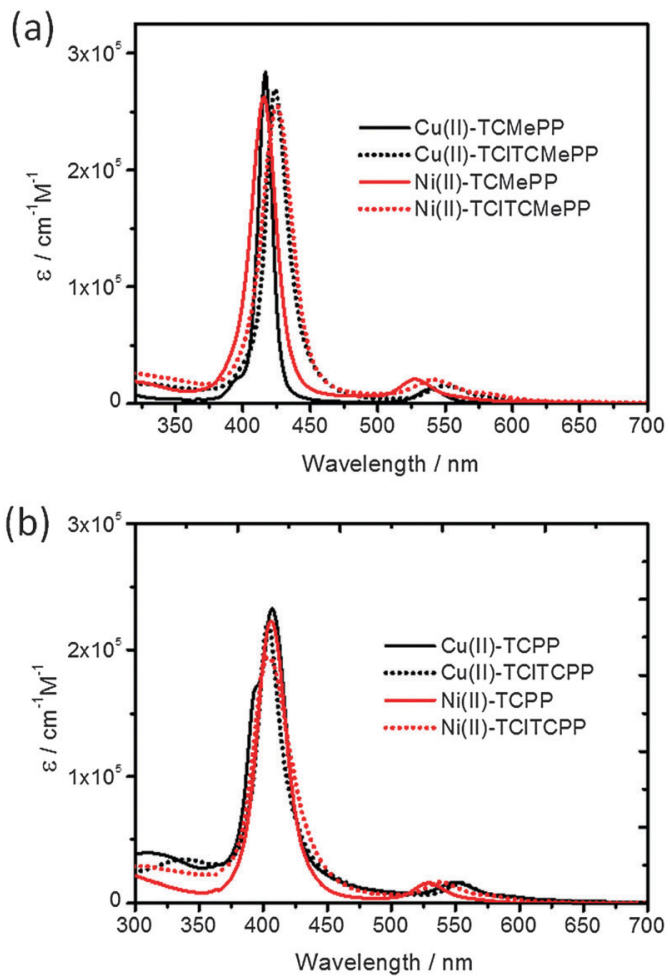

Fig. 2 UV-visible absorption spectra (molar absorption coefficient $\varepsilon$ ) of $\mathrm{Cu}(I)$ and $\mathrm{Ni}(I)$-porphyrin photosensitizers (a) esters in $\mathrm{CH}_{2} \mathrm{Cl}_{2}$ and (b) carboxylic acids in $0.1 \mathrm{M} \mathrm{KPi}$ solution at $\mathrm{pH}$ 7.0.

observed in $\mathrm{Cu}$ (II)-TClTCMePP and Ni(II)-TClTCMePP, compared to the nonhalogenated analogs. Moreover, spectral broadening is also usually observed for halogenated porphyrins as a result of the distorted macrocycle. ${ }^{39}$ The spectral red shifts and broadening improve the light-harvesting properties of the photosensitizers. ${ }^{37}$ The photon-capture ability under solar irradiation will be discussed later. In order to carry out homogeneous threecomponent light-driven water oxidation studies, water-soluble metalloporphyrins were prepared by hydrolysis of the ester groups. Small spectral red-shifts of the Q-bands in Cu(II)-TCITCPP and $\mathrm{Ni}(\mathrm{II})$-TClTCPP are observed in $0.1 \mathrm{M}$ KPi solution compared to the corresponding esters in $\mathrm{CH}_{2} \mathrm{Cl}_{2}$. The excited state energies were determined with steady state luminescence spectroscopy in solution (deoxygenated by Ar purging) at room temperature $\left(21{ }^{\circ} \mathrm{C}\right)$. The emission spectra are shown in Fig. S1 (ESI $\dagger$ ). $\mathrm{Cu}$ (II)-TClTCMePP in $\mathrm{CH}_{2} \mathrm{Cl}_{2}$ shows emission at shorter wavelengths than $\mathrm{Cu}$ (II)-TCMePP (Fig. S1(a), ESI $\dagger$ ). This phenomenon was also observed in other $\mathrm{Cu}(\mathrm{II})$-porphyrins with modified $5,10,15,20$-tetraphenyl groups. ${ }^{40}$ Surprisingly, there is only a small shift in wavelength between $\mathrm{Cu}(\mathrm{II})$-TCPP and $\mathrm{Cu}(\mathrm{II})$-TClTCPP in phosphate buffer solution (Fig. S1(b), ESI $†$ ). The deduced values of triplet state energies $E\left(T_{1}\right)$ are shown in Table 1. For none of the $\mathrm{Ni}(\mathrm{II})$-porphyrins emission could be detected. ${ }^{41}$ Therefore, we used the value of $E\left(T_{1}\right)=1.18 \mathrm{eV}(1051 \mathrm{~nm})$ reported in the literature for $\mathrm{Ni}(\mathrm{II})$-TPP for all nickel-porphyrins. ${ }^{42}$ Excited state lifetimes of the metalloporphyrins were determined with nanosecond transient absorption (ns-TA) and time-resolved emission spectroscopy (Fig. S2-S5, ESI $\dagger$ ). ${ }^{43,44}$ Emissive lifetimes of copper porphyrins have been reported to show a large variation (from 300 to $15 \mathrm{~ns}$ ) and to be influenced by penta-coordination by e.g. the solvent. Triplet-quartet and triplet-doublet states (and fast sub-ns components related to their equilibration) play a role as well as vibronic distortions. ${ }^{45,46}$ This complex behaviour is reflected in the multiexponential emission decays and ns-TA data observed here. $\mathrm{Cu}$ (II)-TCMePP and $\mathrm{Cu}$ (II)-TCPP show the longest lifetimes (28 ns and 12 ns respectively) next to one or two shorter components. The tetrachloro compounds ( $\mathrm{Cu}$ (II)-TClTCMePP and $\mathrm{Cu}$ (II)-TClTCPP) display only short (sub ns) lifetimes (see Table S1, ESI†).

Cyclic voltammetry was performed with all metalloporphyrins in $\mathrm{CH}_{2} \mathrm{Cl}_{2}$, containing $0.1 \mathrm{M}$ tetrabutyl-ammonium hexafluorophosphate, $\left(\mathrm{NBu}_{4} \mathrm{PF}_{6}\right)$. In addition, the water-soluble compounds were studied in $0.2 \mathrm{M} \mathrm{KPi}$ as electrolyte (see ESI $\dagger$ ). In order to unite all potentials for the water oxidation reaction, all the oxidation potentials of metalloporphyrins are referenced to NHE. The potential was determined using the ferrocene/ferrocenium redox couple as an internal standard and the half-wave potential $\left(E_{1 / 2}\right)$ was taken as $0.690 \mathrm{~V} v$ s. NHE in dichloromethane. ${ }^{47,48}$

For the nonhalogenated derivatives of the metallo-porphyrins in dichloromethane two quasi-reversible one-electron redox processes are observed with midpoint potentials $E_{1 / 2}\left(\mathrm{PS}^{\bullet+} / \mathrm{PS}\right)=1.32$ and $E_{1 / 2}\left(\mathrm{PS}^{2+} / \mathrm{PS}^{\bullet+}\right)=1.69 \mathrm{~V} v$ s. NHE for $\mathrm{Cu}(\mathrm{II})$-TCMePP (Fig. 3(a)) and $E_{1 / 2}$ of 1.37 and $1.66 \mathrm{~V} v$ s. NHE in Ni(II)-TCMePP (Fig. 3(b)).

The electron withdrawing character of the chlorine substituents is expected to influence significantly the electrochemical
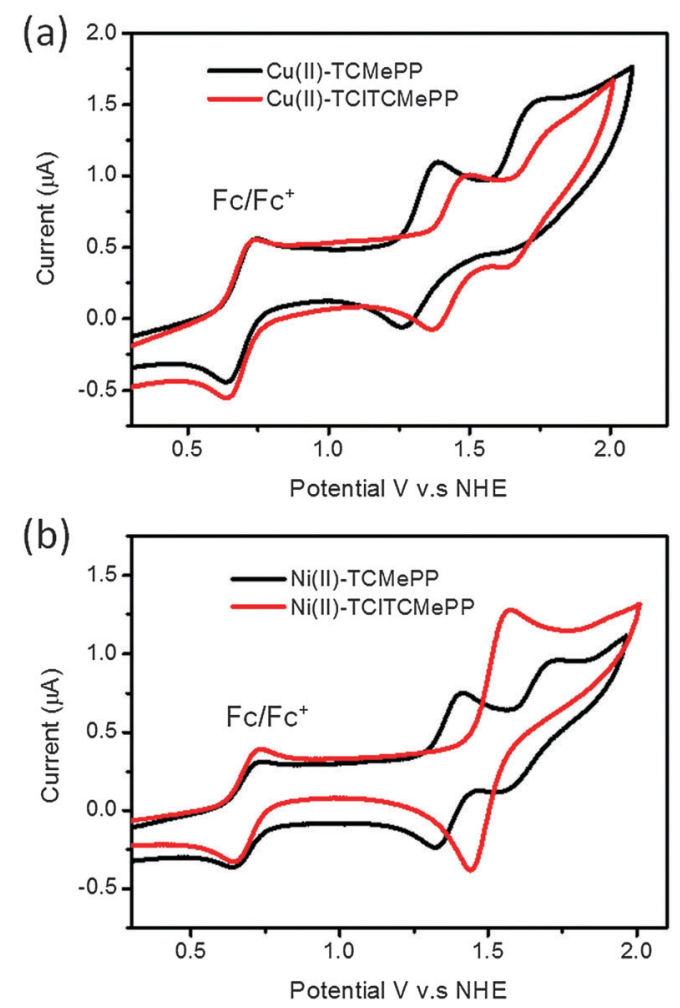

Fig. 3 Cyclic voltammograms of (a) Cu(I)-TCMePP, Cu(II)-TCITCMePP and (b) Ni(I)-TCITCMePP, Ni(I)-TCITCMePP; concentrations $1.0 \mathrm{mM}$ in $\mathrm{CH}_{2} \mathrm{Cl}_{2}$ solution with $0.1 \mathrm{M} \mathrm{NBu}_{4} \mathrm{PF}_{6}$ electrolyte, scan rate $100 \mathrm{mV} \mathrm{s}^{-1}$. $\mathrm{Fc} / \mathrm{FC}^{+}$used as internal standard and $\mathrm{NHE}=\mathrm{Fc} / \mathrm{FC}^{+}+0.69 \mathrm{~V} .{ }^{47,48}$ 
properties of the porphyrin derivatives. ${ }^{34,49}$ Higher potentials for oxidation can clearly be observed for the tetrachlorometalloporphyrins as compared to the nonhalogenated analogs. $E_{1 / 2}\left(\mathrm{PS}^{\bullet+} / \mathrm{PS}\right)$ values of $1.44 \mathrm{~V}$ vs. NHE for $\mathrm{Cu}(\mathrm{II})$-TClTCMePP and $1.51 \mathrm{~V} v s$. NHE for Ni(II)-TClTCMePP were obtained. These more positive potentials for oxidation of the tetrachlorometalloporphyrins imply that their radical cations could provide a larger driving force to activate the water oxidation catalysts. For water-soluble metalloporphyrins, the presence of four negatively charged peripheral benzoate substituents can alter the redox potentials in KPi solution. All potentials of the water-soluble metalloporphyrin are 150-200 $\mathrm{mV}$ lower than those of the waterinsoluble analogs with methyl benzoate substituents. However, also in phosphate buffer, there is a clear difference between tetrachloro-metalloporphyrins and the non-halogenated analogs. Importantly, the highest $E\left(\mathrm{PS}^{\bullet+} / \mathrm{PS}\right)$ of $1.33 \mathrm{~V} v s$. NHE was obtained for Ni(II)-TClTCPP in KPi solution (see Table 1). This indicates that $\mathrm{Ni}(\mathrm{II})$-TCITCPP has enough electron transfer driving force to activate WOCs with moderate overpotentials $(\sim 400 \mathrm{mV})$ at neutral $\mathrm{pH}$ with standard potential of $0.82 \mathrm{~V} v s$. NHE for water oxidation.

\section{Electrocatalytic water oxidation by Co-based catalysts}

$\mathrm{Co}_{4} \mathrm{O}_{4}$-cubane and $\mathrm{Co}\left(\mathrm{NO}_{3}\right)_{2}$ as pre-catalyst for cobalt oxide nanoparticle are known active catalysts for water oxidation reactions in phosphate buffer solution. ${ }^{7,35}$ Electrochemistry was used to characterize these Co-based catalytic systems. Cyclic voltammetry of a solution containing $1 \mathrm{mM} \mathrm{Co}_{4} \mathrm{O}_{4}$-cubane in $0.2 \mathrm{M} \mathrm{KPi}$ buffer as electrolyte at $\mathrm{pH} 7$ to $\mathrm{pH} 10$ is shown in Fig. 4. Considering the onset of the anodic current due to water oxidation (assumed as the potential at which the current intensity reaches $40 \mu \mathrm{A}$ ), the electrocatalytic potential depends on the $\mathrm{pH}$ : it is $+1.33 \mathrm{~V} v s$. NHE at $\mathrm{pH} 7,+1.29 \mathrm{~V}$ vs. NHE at $\mathrm{pH} 8$, $+1.23 \mathrm{~V} v s$. NHE at $\mathrm{pH} 9$ and $+1.15 \mathrm{~V} v s$. NHE at $\mathrm{pH} 10$. This is in agreement with the $\mathrm{pH}$ dependence of the water oxidation potential. ${ }^{50}$ In addition, the increasing anodic current intensity observed by increasing the $\mathrm{pH}$ of the solution indicates that the buffer anions promote the proton-coupled electron transfer in the water oxidation reaction. ${ }^{26}$

For the heterogeneous cobalt oxide nanoparticle water oxidation catalyst, cyclic voltammetry of a solution containing $2 \mathrm{mM}$ $\mathrm{Co}\left(\mathrm{NO}_{3}\right)_{2}$ in $0.2 \mathrm{M}$ phosphate buffer as electrolyte at $\mathrm{pH} 7$ showed

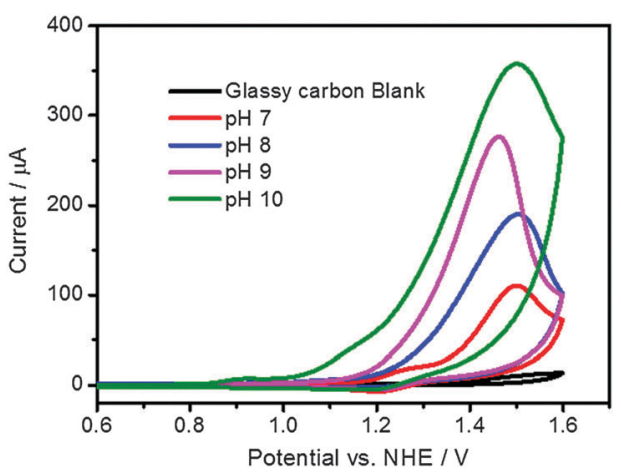

Fig. 4 Cyclic voltammograms of water oxidation by $\mathrm{CO}_{4} \mathrm{O}_{4}$-cubane $(2 \mathrm{mM})$ in $0.2 \mathrm{M} \mathrm{KPi}$ at $\mathrm{pH} 7$ to $\mathrm{pH} 10$.
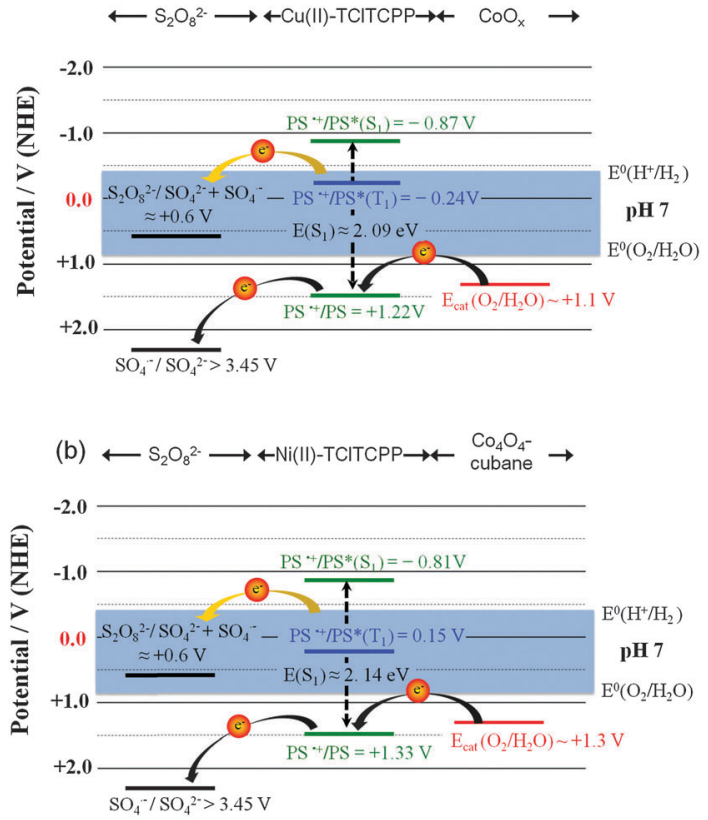

Fig. 5 Energy schemes of halogenated metalloporphyrin photosensitizer (PS) and water oxidation catalysts. (a) $\mathrm{Cu}(I)$-TCITCPP with $\mathrm{CoO}_{x}$ nanoparticles and (b) $\mathrm{Ni}(I)$-TCITCPP with $\mathrm{CO}_{4} \mathrm{O}_{4}$-cubane in phosphate buffer $(\mathrm{pH} 7.0)$ solution. Herein, $E^{O}\left(\mathrm{O}_{2} / \mathrm{H}_{2} \mathrm{O}\right)=+0.82 \mathrm{~V}$ and $E^{O}\left(\mathrm{H}^{+} / \mathrm{H}_{2}\right)=-0.41 \mathrm{~V}$.

a small oxidation peak at $1.21 \mathrm{~V}$ (vs. NHE) that is due to $\mathrm{Co}^{\mathrm{III} / \mathrm{II}}$ oxidation, followed by a rapidly growing catalytic oxidation wave as shown in Fig. S9 (ESI $\dagger$ ). Moreover, an appreciable onset catalytic current at $\sim 1.1 \mathrm{~V}$ (vs. NHE) corresponding to $\eta=280 \mathrm{mV}$ at $\mathrm{pH} 7.0$ can be observed. This result is consistent with recent work on CoPi. ${ }^{28,51}$

The photophysical and electrochemical data were used to construct energy level diagrams of PS, cobalt based WOCs and sacrificial electron acceptor $\left(\mathrm{K}_{2} \mathrm{~S}_{2} \mathrm{O}_{8}\right)$ in phosphate buffer at pH 7.0 (Fig. 5). ${ }^{52}$

The singlet excited state energies of $\mathrm{Cu}(\mathrm{II})$-TClTCPP and $\mathrm{Ni}(\mathrm{II})$-TClTCPP are estimated by their $Q_{\mathrm{y}}$ absorption wavelength. Thermodynamically favorable one-electron transfer from photogenerated triplet-state to $\mathrm{S}_{2} \mathrm{O}_{8}{ }^{2-}$ in buffer solution could be observed in both photocatalytic systems. In Cu(II)-TCITCPP case (Fig. 5(a)), the Cu(II)-TClTCPP radical cation with $E\left(\mathrm{PS}^{\bullet+} / \mathrm{PS}\right)=$ $+1.22 \mathrm{~V}$ (vs. NHE) is thermodynamically capable of driving $\mathrm{CoO}_{x}$ nanoparticle to oxidize water to $\mathrm{O}_{2}$. In Ni(II)-TClTCPP case (Fig. 5(b)), the Ni(II)-TClTCPP radical cation with $E\left(\mathrm{PS}^{\bullet+} / \mathrm{PS}\right)=$ $+1.33 \mathrm{~V}$ (vs. NHE) is capable to activate $\mathrm{Co}_{4} \mathrm{O}_{4}$-cubane. The sulfate radical released from $\mathrm{S}_{2} \mathrm{O}_{8}{ }^{2-}$ can further oxidize the ground state of the halogenated metalloporphyrin, or the WOC if present in sufficiently high concentration. ${ }^{53}$

\section{Visible-light driven water oxidation}

To investigate the activities of visible light driven water oxidation we employed a three-component system composed of a water-soluble metalloporphyrin as the photosensitizer, potassium persulfate $\left(\mathrm{K}_{2} \mathrm{~S}_{2} \mathrm{O}_{8}\right)$ as a sacrificial electron acceptor, and $\mathrm{Co}_{4} \mathrm{O}_{4}$-cubane as a catalyst or $\mathrm{Co}\left(\mathrm{NO}_{3}\right)_{2}$ as pre-catalyst in concentrated phosphate buffer (0.1 M KPi) solution. The photochemical oxygen generation 
was recorded by means of a Clark oxygen electrode under $120 \mathrm{~W}$ halogen lamp illumination. The $\mathrm{O}_{2}$ generation in this photocatalytic system is believed to follow the well-established reaction mechanism presented in Scheme 1.

By using the electrochemical potentials of the water-soluble metalloporphyrin photosensitizers and the electrocatalytic water oxidation results in phosphate buffer solution, the energy relationships between photosensitizers and catalysts can be estimated. In principle, the redox potential of the radical cation of the water-soluble photosensitizer should be higher than the onset of the catalytic potential of the catalyst ${ }^{54}$ in order to get catalysis. However, both the $E\left(\mathrm{PS}^{\bullet+} / \mathrm{PS}\right)$ value of $+1.13 \mathrm{~V} v s$. NHE for $\mathrm{Cu}$ (II)-TCPP and $+1.22 \mathrm{~V}$ vs. NHE observed for $\mathrm{Cu}(\mathrm{II})$-TClTCPP are less than the onset catalytic potential $\left(+1.33 \mathrm{~V} v s\right.$. NHE) of $\mathrm{Co}_{4} \mathrm{O}_{4}$ cubane at $\mathrm{pH}$ 7. Therefore, the $\mathrm{Cu}(\mathrm{II})$-porphyrin photosensitizers were further studied coupled to $\mathrm{Co}_{4} \mathrm{O}_{4}$-cubane at a higher $\mathrm{pH}$. Herein, the turnover number is defined as $\mathrm{TON}=\left[\mathrm{O}_{2}\right] /[$ catalyst $]$. The slope of the initial oxygen evolution is used to determine the maximum turnover frequency $\left(\mathrm{TOF}_{\max }=\mathrm{d}[\mathrm{TON}] / \mathrm{d} t\right)$.

Fig. 6(a) and (b) show the time courses of photocatalytic $\mathrm{O}_{2}$ generation by $\mathrm{Co}_{4} \mathrm{O}_{4}$-cubane with $\mathrm{Cu}$ (II)-TCPP and $\mathrm{Cu}$ (II)TClTCPP as photosensitizers. Clearly, Cu(II)-TCPP shows only very little production of $\mathrm{O}_{2}$, even at $\mathrm{pH} 10$. For $\mathrm{Cu}$ (II)-TClTCPP, on the other hand, the $\mathrm{O}_{2}$ yield is substantial for $\mathrm{pH}>8$. The $\mathrm{TOF}_{\max }=1.1 \times 10^{-3} \mathrm{~s}^{-1}$ at pH 9 increased to $\mathrm{TOF}_{\max }=3.0 \times$ $10^{-3} \mathrm{~s}^{-1}$ at $\mathrm{pH}$ 10. Fig. 6(c) shows photocatalytic water oxidation activities with $\mathrm{Co}\left(\mathrm{NO}_{3}\right)_{2}$ as precatalyst with both $\mathrm{Cu}$ (II)-porphyrins at $\mathrm{pH}$ 7.0. A considerable $\mathrm{O}_{2}$ yield was only observed for $\mathrm{Cu}$ (II)-TClTCPP. Because the reduction potential of $\mathrm{Cu}$ (II)-TClTCPP ${ }^{\bullet+}$ at $+1.22 \mathrm{~V}$ is higher than the onset catalytic current at $+1.1 \mathrm{~V}$ of $\mathrm{Co}\left(\mathrm{NO}_{3}\right)_{2}$ (Fig. S6, ESI $\dagger$ ), $\mathrm{Cu}$ (II)-TClTCPP ${ }^{\bullet+}$ is thermodynamically capable to induce water oxidation by nanoparticles generated in situ from $\mathrm{Co}\left(\mathrm{NO}_{3}\right)_{2}$ in $\mathrm{pH} 7.0 \mathrm{KPi}$ buffer solution.

Fig. 7 shows the time courses of photocatalytic $\mathrm{O}_{2}$ generation by (a) $\mathrm{Co}_{4} \mathrm{O}_{4}$-cubane (b) $\mathrm{Co}\left(\mathrm{NO}_{3}\right)_{2}$ precatalyst with $\mathrm{Ni}(\mathrm{II})$-TCPP and $\mathrm{Ni}(\mathrm{II})$-TClTCPP as photosensitizers at $\mathrm{pH}$ 7.0. Both results show that only the $\mathrm{Ni}$ (II)-TClTCPP sensitizer leads to $\mathrm{O}_{2}$ production. This conclusion is in agreement with the cyclic voltammetry (CV) of $\mathrm{Co}_{4} \mathrm{O}_{4}$-cubane or the $\mathrm{Co}\left(\mathrm{NO}_{3}\right)_{2}$ precatalyst and $\mathrm{Ni}(\mathrm{II})$ TClTCPP at $\mathrm{pH}$ 7.0. The potential of oxidation of Ni(II)-TCITCPP (1.33 V vs. NHE) is higher than the onset of the catalytic wave due to water oxidation of $\mathrm{Co}_{4} \mathrm{O}_{4}$-cubane $(\sim 1.3 \mathrm{~V}$ vs. NHE) or the $\mathrm{Co}\left(\mathrm{NO}_{3}\right)_{2}$ precatalyst $(1.1 \mathrm{~V} v s$. NHE). Therefore, Ni(II)TClTCPP $^{\bullet+}$ is thermodynamically capable of promoting water oxidation with these two Co-based catalysts in neutral phosphate buffer solution. The potential of $\mathrm{Ni}(\mathrm{II})-\mathrm{TCPP}^{\bullet+}$ is too low to efficiently oxidize the catalysts. It is interesting to note that the $\mathrm{Co}_{4} \mathrm{O}_{4}$-cubane, which has a larger overpotential than the $\mathrm{Co}\left(\mathrm{NO}_{3}\right)_{2}$ derived catalyst, gives a substantially higher TOF with the Ni(II)-TClTCPP photosensitizer.

\section{Light control experiment of the photochemical water oxidation}

A light control experiment shows that the catalytic water oxidation in our systems is truly driven by light (Fig. 8). These results clearly confirm the light-driven water oxidation by the Co-based catalysts and halogenated metalloporphyrins
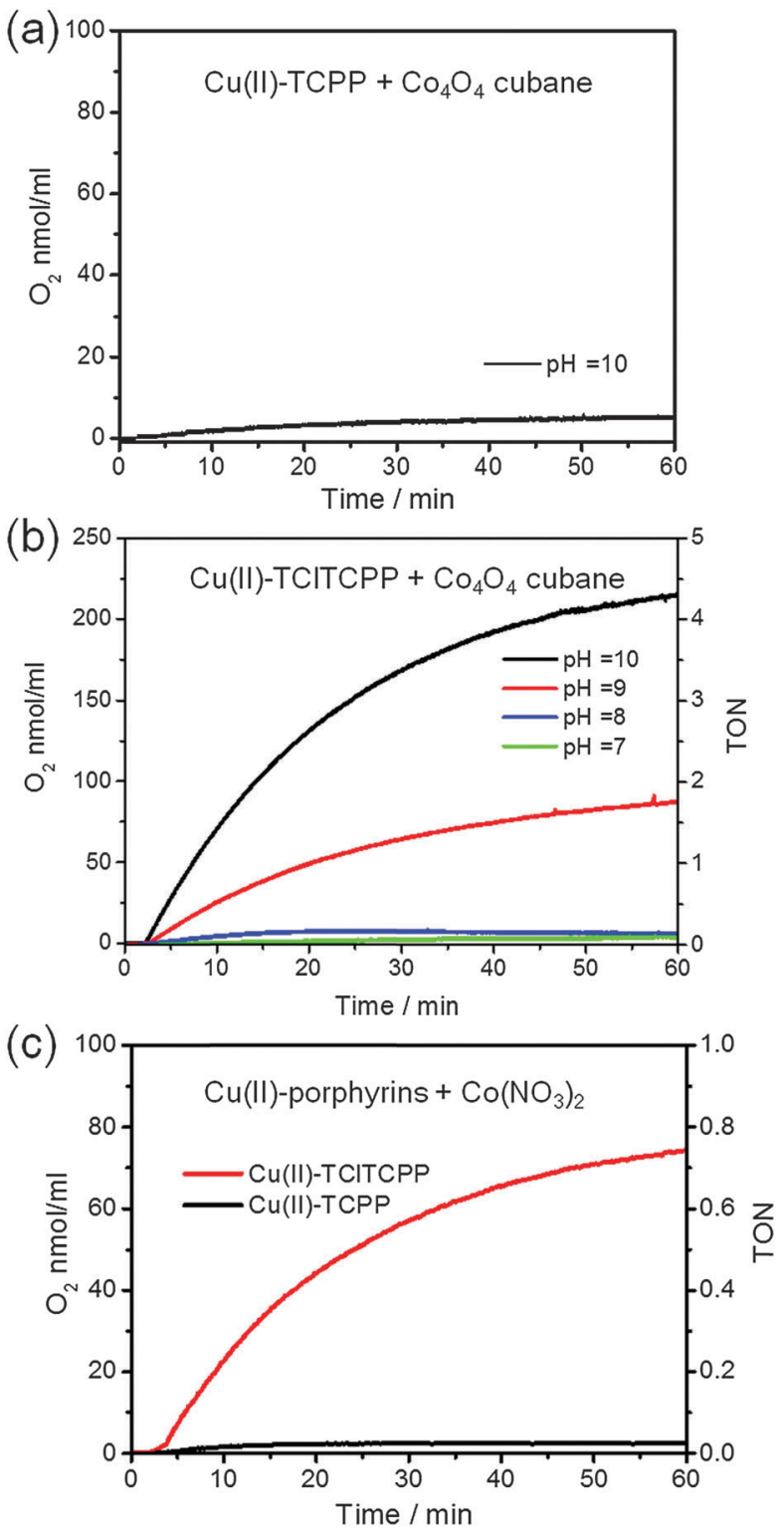

Fig. 6 Photochemical oxygen evolution in $1.5 \mathrm{~mL}$ of $0.1 \mathrm{M}$ KPi buffer solutions containing $\mathrm{K}_{2} \mathrm{~S}_{2} \mathrm{O}_{8}\left(5.0 \times 10^{-2} \mathrm{M}\right)$, $\mathrm{Cu}(॥)$-porphyrin photosensitizers $\left(6.7 \times 10^{-4} \mathrm{M}\right)$ and water oxidation catalysts: (a) $\mathrm{Co}_{4} \mathrm{O}_{4}$-cubane $\left(5.0 \times 10^{-5} \mathrm{M}\right)$ at $\mathrm{pH} 10.0$ with $\mathrm{Cu}(\mathrm{II})-\mathrm{TCPP}$, (b) $\mathrm{CO}_{4} \mathrm{O}_{4}$-cubane $\left(5.0 \times 10^{-5} \mathrm{M}\right)$ at $\mathrm{pH} 7.0$ to $\mathrm{pH} 10.0$ with $\mathrm{Cu}(\mathrm{II})-\mathrm{TCITCPP}$, (c) $\mathrm{Co}\left(\mathrm{NO}_{3}\right)_{2}\left(1.0 \times 10^{-4} \mathrm{M}\right)$ at $\mathrm{pH} 7.0$ with both $\mathrm{Cu}(\Perp)$ porphyrins.

$(\mathrm{Cu}(\mathrm{II})$ and $\mathrm{Ni}(\mathrm{II}))$. A slight $\left[\mathrm{O}_{2}\right]$ decrease during the "off" period was observed which results from equilibration of dissolved oxygen with the headspace. Importantly, the production of oxygen in Fig. 8 can be observed for several hours. This indicates that the halogenated metalloporphyrins are photostable throughout the whole experiment. Fig. S10 (ESI $\dagger$ ) shows the color pictures and absorption spectra of the photocatalytic solutions before and after the time course of illumination. Both nonhalogenated metalloporphyrins (Cu(II)-TCPP and Ni(II)-TCPP) changed from red to dark brown, respectively. This indicates that decomposition of $\mathrm{Cu}(\mathrm{II})-\mathrm{TCPP}$ and $\mathrm{Ni}(\mathrm{II})$-TCPP occurs during the illumination. In contrast, it can be seen by eye that the 


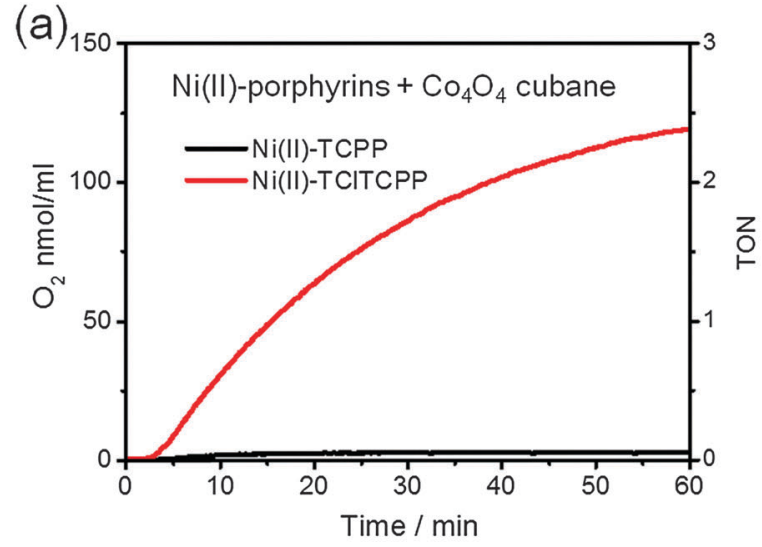

(b)

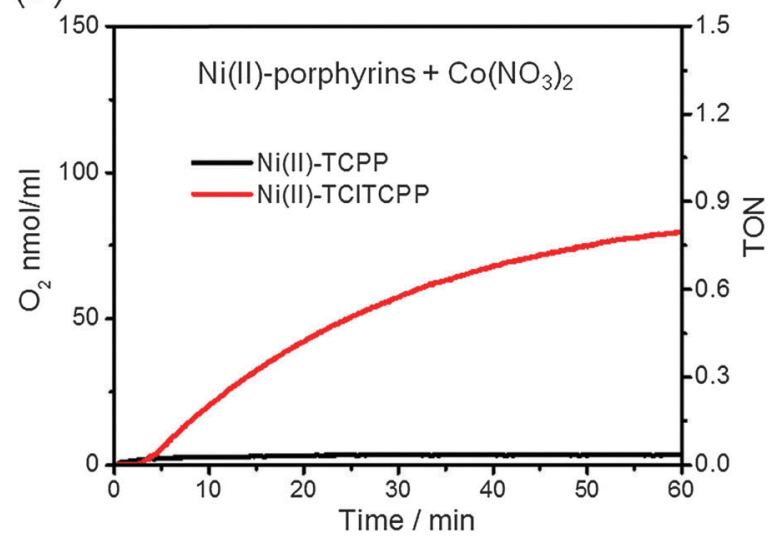

Fig. 7 Photochemical oxygen evolution in $1.5 \mathrm{~mL}$ of $\mathrm{pH} 7.0,0.1 \mathrm{M} \mathrm{KPi}$ buffer solutions containing $\mathrm{K}_{2} \mathrm{~S}_{2} \mathrm{O}_{8}\left(5.0 \times 10^{-2} \mathrm{M}\right)$, Ni(II)-porphyrin photosensitizers $\left(6.7 \times 10^{-4} \mathrm{M}\right)$ and water oxidation catalysts: (a) $\mathrm{Co}_{4} \mathrm{O}_{4}$-cubane $\left(5.0 \times 10^{-5} \mathrm{M}\right),(\mathrm{b}) \mathrm{Co}\left(\mathrm{NO}_{3}\right)_{2}\left(1.0 \times 10^{-4} \mathrm{M}\right)$.

halogenated metalloporphyrins (Cu(II)-TCITCPP and Ni(II)-TCITCPP) in Fig. S9(b) and (d) (ESI $\dagger$ ), are stable as the color of solution before and after illumination is identical. This visual impression is more quantitatively supported by a comparison of the UV-Vis absorption spectra. ${ }^{13}$ The absorption spectra (Fig. S10(b) and (d), ESI $\dagger$ ) of both halogenated metalloporphyrins were still identical with the initial spectra.

We conclude that tetrachlorination at the $\beta$-pyrrole positions of tetraarylporphyrins dramatically improves the photo-stability of the porphyrin photosensitizers. In addition, two metalloporphyrins ( $\mathrm{Cu}(\mathrm{II})-\mathrm{TClTCPP}$ and $\mathrm{Ni}$ (II)-TClTCPP) with the same tetrachloro-porphyrin macrocycle show long term photostability in photocatalytic water oxidation. This indicates that photostability is a property of the tetrachloro-porphyrin macrocycle, not related to the central metal in tetrachloro-metalloporphyrins.

\section{The advantages of a tetrachloro metallo-tetraarylporphyrins for sunlight driven water oxidation}

One of the essential properties of photoactive chromophores applied to molecule-based artificial photosynthetic devices is their ability to capture photons over a large part of the solar spectrum. Fig. S11(a) (ESI $\dagger$ ) shows the UV-Vis spectra of the four chromophores: $\mathrm{Cu}$ (II)-TClTCMePP, Ni(II)-TClTCMePP, Ru(bpy) ${ }_{3}{ }^{2+}$,
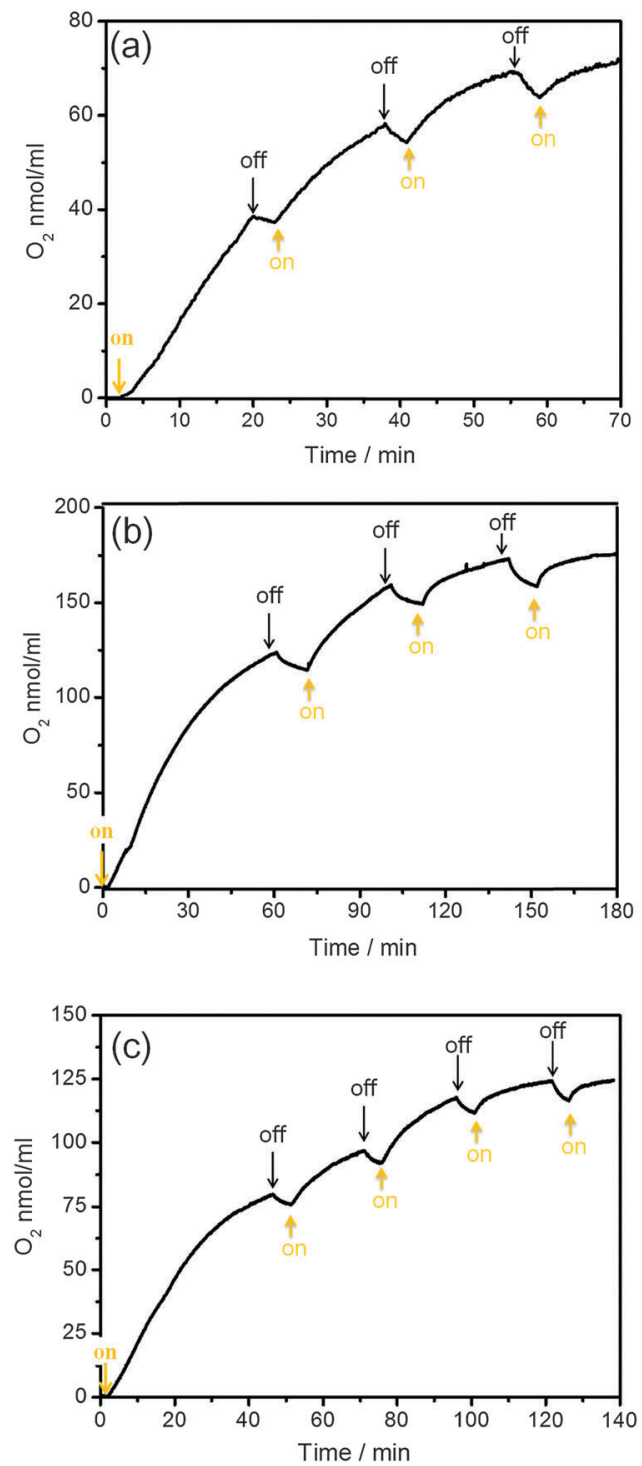

Fig. 8 Photochemical oxygen evolution with switching on/off excitation light in $1.5 \mathrm{~mL}$ of $\mathrm{pH} 7.0,0.1 \mathrm{M} \mathrm{KPi}$ buffer solutions containing $\mathrm{K}_{2} \mathrm{~S}_{2} \mathrm{O}_{8}$ $\left(5.0 \times 10^{-2} \mathrm{M}\right)$ with (a) $\mathrm{Cu}(\mathrm{I})$-TCITCPP $\left(6.7 \times 10^{-4} \mathrm{M}\right)$ and $\mathrm{Co}\left(\mathrm{NO}_{3}\right)_{2}$ precatalyst $\left(1.0 \times 10^{-4} \mathrm{M}\right)$; (b) $\mathrm{Ni}(\mathrm{II})$-TCITCPP $\left(6.7 \times 10^{-4} \mathrm{M}\right)$ and $\mathrm{CO}_{4} \mathrm{O}_{4}{ }^{-}$ cubane $\left(5.0 \times 10^{-5} \mathrm{M}\right)$; (c) $\mathrm{Ni}(\mathrm{I})-\mathrm{TCITCPP}\left(6.7 \times 10^{-4} \mathrm{M}\right)$ and $\mathrm{Co}\left(\mathrm{NO}_{3}\right)_{2}$ precatalyst $\left(1.0 \times 10^{-4} \mathrm{M}\right)$.

and $\mathrm{Chl} a$ (related to the monomer of P680 in natural oxygenic photosynthesis). In addition, Fig. S11(b) (ESI $\dagger$ ) shows the photon absorption rates by $2 \mu \mathrm{M}$ solutions of chromophores under AM1.5G sunlight in the range 300 to $730 \mathrm{~nm}$. The integrated molar absorptivities and percentages of photons absorbed by $2 \mu \mathrm{M}$ chromophore solutions are shown in Table 2 . Both the values for $\mathrm{Cu}(\mathrm{II})$-TClTCMePP and Ni(II)-TClTCMePP are at least five times larger than those of $\mathrm{Ru}(\mathrm{bpy})_{3}{ }^{2+}$ because they show much more intense absorption in the visible light range. Another parameter representing the photon-absorption ability of a chromophore is the $50 \%$ photon capture threshold $\left(\mathrm{PCT}^{50}\right),{ }^{55}$ which is the concentration of a chromophore needed to absorb $50 \%$ of incident solar photons in the given solar spectrum range. The $\mathrm{PCT}^{50}$ of $\mathrm{Cu}(\mathrm{II})$-TClTCMePP and Ni(II)-TClTCMePP are about one order 
Table 2 Photo-absorption properties ${ }^{a}$ of representative chromophores referenced to AM1.5G solar irradiance photon flux and related redox potential $E\left(\mathrm{PS}^{\bullet+} / \mathrm{PS}\right)$

\begin{tabular}{|c|c|c|c|c|}
\hline Molecule & $\begin{array}{l}\text { Integrated molar } \\
\text { absorptivity }^{b}\left(\mathrm{M}^{-1}\right)\end{array}$ & $\begin{array}{l}\text { AM1.5G photon } \\
\text { capture }^{c}(2 \mu \mathrm{M})\end{array}$ & $\begin{array}{l}50 \% \text { photon capture } \\
\text { threshold }^{d}\left(\mathrm{PCT}^{50}\right)\end{array}$ & $\begin{array}{l}\text { Redox potential } \\
\text { V vs. NHE }\end{array}$ \\
\hline $\mathrm{Cu}(\mathrm{II})$-TClTCMеPP & $6.5 \times 10^{8}$ & $9.6 \%$ & $32 \mu \mathrm{M}$ & 1.44 \\
\hline Ni(II)-TClTCMePP & $7.0 \times 10^{8}$ & $10.3 \%$ & $31 \mu \mathrm{M}$ & 1.51 \\
\hline $\mathrm{Ru}(\mathrm{bpy})_{3}{ }^{2+}$ & $1.2 \times 10^{8}$ & $1.7 \%$ & $360 \mu \mathrm{M}$ & $1.26^{f}$ \\
\hline Chlorophyll $a$ & $4.8 \times 10^{8}$ & $7.2 \%$ & $38 \mu \mathrm{M}$ & $0.81^{g, h}$ \\
\hline P680 & & & & $1.26^{i}$ \\
\hline
\end{tabular}

${ }^{a} 300-730 \mathrm{~nm} .{ }^{b}$ The absorption spectra of Ru(bpy $)_{3}{ }^{2+}$ and chlorophyll $a$ are from ref. $56 .{ }^{c}$ Percentage of incident solar photons absorbed for a solution of a given concentration $\left(1 \mathrm{~cm}\right.$ path length). ${ }^{d}$ Concentration required to absorb $50 \%$ of the incident solar photons $(1 \mathrm{~cm}$ path length).

${ }^{e}$ Ref. 22. ${ }^{f}$ Ref. 54. ${ }^{g}$ Ref. 57. ${ }^{h}$ Ref. 58 herein, NHE $=$ SHE +6 mV. ${ }^{i}$ Ref. 59. ${ }^{j}$ Ref. 60.

smaller than that of $\mathrm{Ru}(\mathrm{bpy})_{3}{ }^{2+}$. Moreover, compared to our previously reported photoactive chromophore, $\mathrm{Pt}(\mathrm{II})-\mathrm{TCMePP},{ }^{22}$ the broadening and red-shift of absorption by tetrachlorination for $\mathrm{Cu}$ (II)-TClTCMePP and Ni(II)-TClTCMePP make the PCT $^{50}$ a factor four smaller than that of $\mathrm{Pt}(\mathrm{II})-\mathrm{TCMePP}$. The photon absorption rates of $2 \mu \mathrm{M}$ for both tetrachloro-metalloporphyrins are also higher than that of chlorophyll $a$. Even though chlorophyll $a$ has broader bands that span a large portion of the sunlight spectrum, the PCT $^{50}$ values of both of our tetrachlorometalloporphyrins are similar to that of chlorophyll $a$.

The second essential property of a photosensitizer for lightdriven water oxidation is the oxidation potential. ${ }^{19}$ Particularly, the $E_{1 / 2}\left(\mathrm{PS}^{\bullet+} / \mathrm{PS}\right)$ of $\mathrm{Ni}(\mathrm{II})-\mathrm{TClTCMePP}$ is $250 \mathrm{mV}$ higher than $E_{1 / 2}\left(\mathrm{PS}^{\bullet+} / \mathrm{PS}\right)$ of $\mathrm{Ru}(\mathrm{bpy})_{3}{ }^{2+}$. Thus, choosing tetrachlorometalloporphyrins as photosensitizers for light-driven water oxidation not only affords a better light harvesting function under solar excitation but also provides a larger driving force for electron transfer from the WOC to the radical cation of the photosensitizer. We previously studied the noble-metal based photo-active porphyrin, Pt(II)-TCPP, which was shown to be much more photostable in phosphate buffer solution, and to have a better photon capture ability than $\mathrm{Ru}(\mathrm{bpy})_{3}{ }^{2+} .{ }^{22}$ The halogenated metalloporphyrins introduced in the present work provide a further improvement of both properties.

\section{Conclusions}

Tetrachloro-metallo-porphyrins with earth abundant metal ions $\mathrm{Cu}(\mathrm{II})$ and $\mathrm{Ni}(\mathrm{II})$ are very photostable sensitizers for visible-lightdriven water oxidation coupled to cobalt based water oxidation catalysts. The relatively high electrochemical potential of the tetrachloro-metalloporphyrins allows these chromophores to be used to study WOCs with moderate overpotentials $(\sim 400 \mathrm{mV})$ in neutral phosphate buffer solution. Especially Ni(II)-TClTCPP performs well with the $\mathrm{Co}_{4} \mathrm{O}_{4}$-cubane WOC. More importantly, the tetrachloro-metalloporphyrins show exceptionally high photostability in concentrated phosphate buffer solution during light-driven water oxidation. They also show at least five times more solar photon capture ability and $170-250 \mathrm{mV}$ more oxidizing power than the extensively used $\mathrm{Ru}(\mathrm{bpy})_{3}{ }^{2+}$. Moreover, they also show similar oxidation potentials and better solar photon capture abilities relative to the photoactive noble-metal porphyrin, $\mathrm{Pt}(\mathrm{II})-\mathrm{TCMePP} .{ }^{22}$ Therefore, the introduction of halogenated metalloporphyrins with earth-abundant metal ions is a step forward in the development of robust photosensitizers in molecule based artificial photosynthesis.

\section{Acknowledgements}

This work is part of the research program of the Foundation for Fundamental Research on Matter (FOM), which is part of the Netherlands Organisation for Scientific Research (NWO). This research is financed in part by the BioSolar Cells open innovation consortium, supported by the Dutch Ministry of Economic Affairs, Agriculture and Innovation.

\section{References}

1 T. R. Cook, D. K. Dogutan, S. Y. Reece, Y. Surendranath, T. S. Teets and D. G. Nocera, Chem. Rev., 2010, 110, 6474-6502.

2 S. Bensaid, G. Centi, E. Garrone, S. Perathoner and G. Saracco, ChemSusChem, 2012, 5, 500-521.

3 L. Duan, L. Tong, Y. Xu and L. Sun, Energy Environ. Sci., 2011, 4, 3296-3313.

4 S. Romain, L. Vigara and A. Llobet, Acc. Chem. Res., 2009, 42, 1944-1953.

5 D. G. H. Hetterscheid and J. N. H. Reek, Chem. Commun., 2011, 47, 2712-2714.

6 G. C. Dismukes, R. Brimblecombe, G. A. N. Felton, R. S. Pryadun, J. E. Sheats, L. Spiccia and G. F. Swiegers, Acc. Chem. Res., 2009, 42, 1935-1943.

7 N. S. McCool, D. M. Robinson, J. E. Sheats and G. C. Dismukes, J. Am. Chem. Soc., 2011, 133, 11446.

8 J. L. Fillol, Z. Codola, I. Garcia-Bosch, L. Gomez, J. J. Pla and M. Costas, Nat. Chem., 2011, 3, 807-813.

9 M.-T. Zhang, Z. Chen, P. Kang and T. J. Meyer, J. Am. Chem. Soc., 2013, 135, 2048-2051.

10 D. G. H. Hetterscheid and J. N. H. Reek, Angew. Chem., Int. Ed., 2012, 51, 9740-9747.

11 A. Sartorel, M. Carraro, F. M. Toma, M. Prato and M. Bonchio, Energy Environ. Sci., 2012, 5, 5592-5603. 
12 X. Deng and H. Tüysüz, ACS Catal., 2014, 4, 3701-3714.

13 Y. Xu, L. Duan, L. Tong, B. Åkermark and L. Sun, Chem. Commun., 2010, 46, 6506-6508.

14 W. J. Youngblood, S.-H. A. Lee, Y. Kobayashi, E. A. Hernandez-Pagan, P. G. Hoertz, T. A. Moore, A. L. Moore, D. Gust and T. E. Mallouk, J. Am. Chem. Soc., 2009, 131, 926-927.

15 Z. Yu, F. Li and L. Sun, Energy Environ. Sci., 2015, 8, 760-775.

16 S. Berardi, G. La Ganga, M. Natali, I. Bazzan, F. Puntoriero, A. Sartorel, F. Scandola, S. Campagna and M. Bonchio, J. Am. Chem. Soc., 2012, 134, 11104-11107.

17 G. S. Nahor, P. Neta, P. Hambright, A. N. Thompson and A. Harriman, J. Phys. Chem., 1989, 93, 6181-6187.

18 A. Lewandowska-Andralojc and D. E. Polyansky, J. Phys. Chem. A, 2013, 117, 10311-10319.

19 J. R. Swierk and T. E. Mallouk, Chem. Soc. Rev., 2013, 42, 2357-2387.

20 A. Harriman and M. C. Richoux, J. Phys. Chem., 1983, 87, 4957-4965.

21 G. F. Moore, J. D. Blakemore, R. L. Milot, J. F. Hull, H. Song, L. Cai, C. A. Schmuttenmaer, R. H. Crabtree and G. W. Brudvig, Energy Environ. Sci., 2011, 4, 2389-2392.

22 H.-C. Chen, D. G. H. Hetterscheid, R. M. Williams, J. I. van der Vlugt, J. N. H. Reek and A. M. Brouwer, Energy Environ. Sci., 2015, 8, 975-982.

23 J. R. Swierk, D. D. Méndez-Hernández, N. S. McCool, P. Liddell, Y. Terazono, I. Pahk, J. J. Tomlin, N. V Oster, T. A. Moore, A. L. Moore, D. Gust and T. E. Mallouk, Proc. Natl. Acad. Sci. U. S. A., 2015, 112, 1681-1686.

24 The potential of $0.209 \mathrm{~V} v s$. NHE corresponds to $0.0 \mathrm{~V} v s$. $\mathrm{Ag} / \mathrm{AgCl}, \mathrm{NaCl}$.

25 C. J. Gagliardi, A. K. Vannucci, J. J. Concepcion, Z. Chen and T. J. Meyer, Energy Environ. Sci., 2012, 5, 7704-7717.

26 D. Wang and J. T. Groves, Proc. Natl. Acad. Sci. U. S. A., 2013, 110, 15579-15584.

27 M. Hara, C. C. Waraksa, J. T. Lean, B. A. Lewis and T. E. Mallouk, J. Phys. Chem. A, 2000, 104, 5275-5280.

28 M. W. Kanan, Y. Surendranath and D. G. Nocera, Chem. Soc. Rev., 2009, 38, 109-114.

29 D. K. Dogutan, R. McGuire and D. G. Nocera, J. Am. Chem. Soc., 2011, 133, 9178-9180.

30 B. Mondal, K. Sengupta, A. Rana, A. Mahammed, M. Botoshansky, S. G. Dey, Z. Gross and A. Dey, Inorg. Chem., 2013, 52, 3381-3387.

31 D. Dolphin, T. G. Traylor and L. Y. Xie, Acc. Chem. Res., 1997, 30, 251-259.

32 T. G. Traylor and S. Tsuchiya, Inorg. Chem., 1987, 26, 1338-1339.

33 H. Y. Liu, T. S. Lai, L. L. Yeung and C. K. Chang, Org. Lett., 2003, 5, 617-620.

34 P. Ochsenbein, K. Ayougou, J. Fischer, R. Weiss, N. Rachel, K. Jayaraj, A. Gold, J. Terner and J. Fajer, Angew. Chem., Int. Ed., 1994, 33, 348-350.

35 D. Hong, J. Jung, J. Park, Y. Yamada, T. Suenobu, Y.-M. Lee, W. Nam and S. Fukuzumi, Energy Environ. Sci., 2012, 5, 7606-7616.
36 G. F. Swiegers, J. K. Clegg and R. Stranger, Chem. Sci., 2011, 2, 2254.

37 H. Shahroosvand, S. Zakavi, A. Sousaraei and M. Eskandari, Phys. Chem. Chem. Phys., 2015, 17, 6347-6358.

38 T. Takeuchi, H. B. Gray and W. A. Goddard, J. Am. Chem. Soc., 1994, 116, 9730-9732.

39 W. Jentzen, M. C. Simpson, J. D. Hobbs, X. Song, T. Ema, N. Y. Nelson, C. J. Medforth, K. M. Smith and M. Veyrat, J. Am. Chem. Soc., 1995, 117, 11085-11097.

40 K. L. Cunningham, K. M. McNett, R. A. Pierce, K. A. Davis, H. H. Harris, D. M. Falck and D. R. McMillin, Inorg. Chem., 1997, 36, 608-613.

41 R. L. Milot, G. F. Moore, R. H. Crabtree, G. W. Brudvig and C. A. Schmuttenmaer, J. Phys. Chem. C, 2013, 117, 21662-21670.

42 P. Brodard and E. Vauthey, Chem. Phys. Lett., 1999, 309, 198-208.

43 J. A. S. Cavaleiro, H. Görner, P. S. S. Lacerda, J. G. MacDonald, G. Mark, M. G. P. M. S. Neves, R. S. Nohr, H.-P. Schuchmann, C. von Sonntag and A. C. Tomé, J. Photochem. Photobiol., A, 2001, 144, 131-140.

44 T. Kumpulainen, B. H. Bakker, M. Hilbers and A. M. Brouwer, J. Phys. Chem. B, 2015, 119, 2515-2524.

45 J. Rodriguez, C. Kirmaier and D. Holten, J. Am. Chem. Soc., 1989, 111, 6500-6506.

46 M. Asano, Y. Kaizu and H. Kobayashi, J. Chem. Phys., 1988, 89, 6567-6576.

47 N. G. Connelly and W. E. Geiger, Chem. Rev., 1996, 96, 877-910. 48 G. F. Moore, S. J. Konezny, H. Song, R. L. Milot, J. D. Blakemore, M. L. Lee, V. S. Batista, C. A. Schmuttenmaer, R. H. Crabtree and G. W. Brudvig, J. Phys. Chem. C, 2012, 116, 4892-4902.

49 G. A. Spyroulias, A. P. Despotopoulos, C. P. Raptopoulou, A. Terzis, D. de Montauzon, R. Poilblanc and A. G. Coutsolelos, Inorg. Chem., 2002, 41, 2648-2659.

50 Y. Zhao, N. M. Vargas-Barbosa, E. A. Hernandez-Pagan and T. E. Mallouk, Small, 2011, 7, 2087-2093.

51 M. W. Kanan and D. G. Nocera, Science, 2008, 321, 1072-1075.

52 K. Henbest, P. Douglas, M. S. Garley and A. Mills, J. Photochem. Photobiol., A, 1994, 80, 299-305.

53 G. La Ganga, F. Puntoriero, S. Campagna, I. Bazzan, S. Berardi, M. Bonchio, A. Sartorel, M. Natali and F. Scandola, Faraday Discuss., 2012, 155, 177-190.

54 L. Duan, Y. Xu, P. Zhang, M. Wang and L. Sun, Inorg. Chem., 2010, 49, 209-215.

55 M. T. Whited, P. I. Djurovich, S. T. Roberts, A. C. Durrell, C. W. Schlenker, S. E. Bradforth and M. E. Thompson, J. Am. Chem. Soc., 2011, 133, 88-96.

56 J. M. Dixon, M. Taniguchi and J. S. Lindsey, Photochem. Photobiol., 2005, 81, 212-213.

57 M. Kobayashi, S. Ohashi, K. Iwamoto, Y. Shiraiwa, Y. Kato and T. Watanabe, Biochim. Biophys. Acta, 2007, 1767, 596-602.

58 V. V. Pavlishchuk and A. W. Addison, Inorg. Chim. Acta, 2000, 298, 97-102.

59 H. Dau and I. Zaharieva, Acc. Chem. Res., 2009, 42, 1861-1870.

60 Y. Gao, X. Ding, J. Liu, L. Wang, Z. Lu, L. Li and L. Sun, J. Am. Chem. Soc., 2013, 135, 4219-4222. 